CsászÁr Kinga

DOI: 10.15170/DIKE.2018.02.01.10

PhD-jelölt

bíró

Budapesti IV. és XV. Kerületi Bíróság

\title{
Márkus Dezső a nőkérdésről
}

\section{Dezsö Márkus about the Women's Rights}

Deasó" Márkus, judge of the Supreme Court and councilor judge of the Ministry of Justice, was a supporter of women's equalization. He felt responsible to speak about the problems of the socially deprived part of Hungarian society. Thus, in his writings that are described in this paper, he advocated the extension of women's voting rights and opposed the practice of the disciplinary rights of the landholders againts their servans. He felt the need for a change in the legal status of those children who were born out of wedlock. The actuality of his examination was the fact that the drafts of the first Civil Code in Hungary (1900 - 1928) was under editing at the same time and Márkus thought that the legally underprivileged people could get a better status in society under the new act. However, he was aware that it was not yet the time for a radical reform in these areas.

Keywords: women's equalization, socially deprived people, women's voting rights, disciplinary rights, children out of wedlock

„Mindeneket megpróbáljatok: ami jó, ąt megtartsátok.."

Márkus Dęsố munkásságában kiemelkedő helyet foglalt el a társadalom hátrányos helyzetű csoportjaira vonatkozó jogi szabályozás vizsgálata. Tudományos munkásságának vitathatatlan eredménye volt a vonatkozó hatályos normák és a joggyakorlat összefoglalásán túl, hogy nyilvánosságot teremtett az elesettek ügyének támogatása érdekében. Márkus írásaiban e tekintetben elsősorban a nők jogi helyzetének vizsgálatával találkozhatunk, ami további kutatási témákat vont magával: a házasságon kívül született gyermek és a cselédség jogállásának kérdését valamint a női választójog ügyét.

\section{A cselédügy}

Korábbi tanulmányomban vizsgáltam már a 19-20. századfordulójának magyar társadalmában a tipikusan női foglalkozásokat és a cselédség helyzetére vonatkozó jogi szabályozást 1867 és 1918 között. A vizsgálat eredményeként azt a következtetést vontam le, hogy annak ellenére, hogy a cselédek alkalmazása már a 15-16. században jelen volt a gazdaságban és számuk fokozatosan növekedett, hazánkban a 19. század végéig nem volt rájuk vonatkozó, átfogó törvényi szabályozás.

\footnotetext{
${ }^{1}$ Idézet Szent Pál leveléből a thesszalonikai gyülekezethez (I. Thesszalonika 5:21)
} 
Sôt, egyáltalán nem szabályozta törvény a munkaadó és a munkavállaló közötti jogviszonyt, így a felek jogait és kötelezettségeit, a munkabért, a munkaidőt, a szolgálati idôt vagy a felelôsség és felelősségre vonás kérdését. E tekintetben hosszú időn át a szokásjog dominált. A cseléd és a gazda közötti jogviszony az elsô cselédrendtartásoktól (1723 után) a korszak végéig nem sokat változott.

Jogi értelemben egyértelmú megkülönböztetést mutatott a vizsgálat a házi és a gazdasági cselédek között, hiszen az uradalmak számára a legfontosabb a mezőgazdasági munkaerő biztosítása volt. Az első cselédtörvény, amely az 1876. évi XIII. tc. a mezőgazdasági munkások és napszámosok szolgálati viszonyát szabályozta, és az egyetlen olyan törvény volt a vizsgált korszakban, amely a házi (belső) cselédek jogviszonyait is rendezte. Miután a soron következő törvények ezt elmulasztották, a korszak végéig ezen jogszabály - idővel túlhaladott - szabályai vonatkoztak rájuk. Az 1876. évi XIII. tc. azonban a női cselédekre nézve csupán két említést tett, tükrözve a korabeli jogfelfogást. Az előbbi rendelkezések értelmében egyrészt a férjes asszony férje ellenzése esetén nem léphetett szolgálatba, vagy ha szolgálatba lépett, férje visszakövetelhette ôt. Az elszegődött cseléd sem volt köteles szolgálatba lépni, ha időközben férjhez ment és a férje a beleegyezést megtagadta. ${ }^{2}$ A törvény a cselédnő részére is megadta a lehetőséget a szerződés idő előtti megszüntetésére abban az esetben, ha házassága által önállóságra tehetne szert, és a szolgálati idő kitöltése esetén erre nem lenne kilátása. ${ }^{3}$ A női munka védelmének hiányát tükrözte a gazdának biztosított lehetőség arra, hogy a szerződést a felmondási idő előtt is jogszerűen megszüntesse, ha a nőcseléd terhes állapotba jutott. ${ }^{4}$

Az 1907. évi XLV. tc. egészen a korszak végéig megszabta a gazdák és a cselédek közötti jogviszonyt. Látszatra szociális intézkedéseket hozott, lényegében azonban szigorításokat tartalmazott a cselédekkel szemben. ${ }^{5}$ Egyetlen pozitívuma a robot eltörlése volt. A közvélemény azért nevezte „derestörvénynek”, mert a cselédek törvényben biztosított jogai fiktívek voltak, a gazda jóindulatától függött érvényesítésük. ${ }^{6}$ A , ,derestörvény” csak a mezőgazdasági, külső cselédek és a gazdák közötti jogviszonyt szabályozta, illetve azokra terjedt még ki, akik egyszerre szegődtek háztartásbeli és gazdasági munkák végzésére. Tehát a házi cselédségrôl ezúttal is megfeledtkezett a jogalkotó.

Kijelenthetjük, a dualizmus-kori Magyarországon a cselédség gazdasági és szociális szempontból is a legkiszolgáltatottabb helyzetben volt. Ugyanez jogi helyzetüket tekintve is elmondható. Azon kívül, hogy a fizikai és lelki erőszak alkalmazása velük szemben legális volt, politikai jogokat nem kaptak, hiszen a gazda hatalma alatt állóként eleve kizártak őket a választójogból.7 Többnyire emberi méltóságuktól megfosztottan éltek; az intézők és felügyelők korra való tekintet nélkül tegezték őket, és gyakran fizikai bántalmazásnak estek áldozatul. ${ }^{8}$ Kulturáltságuk alacsony fokon állt. Viszonyaikra Somogy vármegyében még 1943-ban is az 1907.

\footnotetext{
2 1876. évi XIII. tc. 9. \, 22. \b

3 1876. évi XIII. tc. 51. \II. b

4 1876. évi XIII. tc. 51. \ I. f

${ }^{5}$ SÁPI, A mezőgazdasági cselédség 301.

6 T. MÉREY, Adatok 3-20.

${ }^{7}$ SÁPI, A mezőgazdasági cselédség 309.

${ }^{8}$ SZILI, Cselédsors 6-9.
} 
évi XLV. tc-et alkalmazták. ${ }^{9}$ A kutatás azt is kimutatta, hogy Somogyban a női dolgozók javarészt cselédnek szegődtek és a házi (belső) cselédek jelentős része nő volt. ${ }^{10}$

Márkus Dęsō a gazda és a gazdasági cseléd közötti jogviszony szabályozásáról szóló 1907. évi törvényjavaslat kapcsán foglalkozott a házi fegyelem kérdésével. Arra a megállapításra jutott, hogy a vizsgálat idején, tehát az 1907. évi cselédtörvény hatálybalépését megelőzően, Magyarországon a házi fegyelem jogának gyakorlására jogosult volt a szülő, illetve a gyám a felügyelete alatt álló kiskorú fölött az 1877. évi XX. tc. alapján, a gazda a cselédje fölött a hatályos cselédtörvény, vagyis az 1876. évi XII. tc. alapján, valamint az iparos a tanonc fölött az ipartörvény (1884. évi XVII. tc.) 66. \-a értelmében. ${ }^{11}$

Márkus Dę̧số kiemelte, hogy a hatályos jog szerint a testi bántalmazásban megnyilatkozó házi fegyelmi jog gyakorlásának a végső határa a nyolc napon belül gyógyuló, könnyú testi sértés bűncselekmény elkövetése volt. A hatályos büntetőtörvény, az 1878. évi V. tc. 313. 』-a szerint ugyanis „a házi fegyelemre jogosított személy által, annak gyakorlatában elkövetett könnyú testi sértés miatt, büntetésnek nincs helye”. Ez azt jelentette, hogy a házi fegyelemre jogosultnak büntetlenül szabad volt a házi fegyelme alatt álló gyermeke, cselédje, tanonca testét „sqándékosan, de ölési szándék nélkül bántalmaznia vagy annak egészségét sértenie, ha az ezáltal okozott sérülés, betegség vagy elmekór nyolc napnál tovább nem tartott’. Amennyiben tehát a házi fegyelemre jogosult e jogát csak szóval, vagyis sértő és gyalázó kifejezésekkel gyakorolta, erre vonatkozó törvényi rendelkezés hiányában, e tekintetben a végletekig mehetett, büntetlenül. Ennek alapján magától értődött volna, mégis a kir. Curia határozatára volt szükség annak megállapításához, hogy a férjnek nincs házi fegyelmi joga feleségével szemben.

A gazda és a gazdasági cseléd közötti jogviszony szabályozásáról szóló törvényjavaslat enyhíteni akart a cselédtörvénynek a házi fegyelmi jogot illető, fent részletezett rendelkezésén, azonban a javaslat nem vonatkozott a házi (belső) cselédekre, akiknek nagy része nő volt. Így 1907 után is fennmaradt az a gyakorlat, hogy a gazda szóval büntetlenül, testi fenyítéssel pedig a nyolc napon belül gyógyuló bántalmazás határáig gyakorolhatta a fenyítés jogát.

Az új törvényjavaslat 3. \-a így csak a külső cselédekre vonatkozott. A cseléd 18 éves koráig maradt a gazda házi fegyelme alatt. Ezt azt jelentette, hogy az 1907. évi cselédtörvény hatályba lépésétől a gazda csak 18 éves koráig bántalmazhatta büntetlenül a külsô cselédet úgy, hogy nyolc napon át beteg legyen, amely a cseléd részéről még felmondási oknak sem volt tekintendő és természetesen még kevésbé az, ha a gazda bármily korú cselédjét bármilyen gyalázó és sértő kifejezésekkel illette. A házi cselédet pedig annak 18. életéve betöltésétől is változatlanul bántalmazhatta.

Márkus Dezsōo a házi fegyelem jogát brutálisnak, az emberi méltósággal és becsülettel össze nem férőnek tartotta, amelyet ki kell küszöbölni törvényeinkből annál is inkább, mert a testi fenyítés hazánkban az 1871. évi LII. tc. hatályba lépése óta megszűnt büntetésnek lenni, vagyis az állam a maga felelős és kvalifikált közegeire sem bízta az e fajta büntetésnek végrehajtását. A szerző véleménye azt volt, hogy a cselédet épp oly szabad munkásként kellene elismernie a hatályos jogrendszernek, mint a többi munkavállalót. A munkaadó és a munkás között létesülő jogviszonyt

\footnotetext{
${ }^{9}$ Az igali járás főszolgabírója 5419/1943. sz. iratát lásd SzILI, Cselédsors (mellékletek)

${ }^{10}$ Lásd bővebben CsÁSZÁr, A cselédség 175.

11 MárkUs, Házi fegyelem 98-101.
} 
pedig, bármilyen munkáról legyen szó, általánosságban egyenlő jogszabályoknak kellene rendezniük. Kiemelte, hogy a porosz, szász cselédrendeleteknek (Gesindeordnung) a házi fegyelemre vonatkozó rendelkezései a német polgári törvénykönyv (BGB) hatályba lépése óta (1900. január 1.) nem érvényesültek. A BGB-t életbe léptető bevezető törvény (Einfübrungsgesetz) 95. cikkének utolsó bekezdése ugyanis az egész Német birodalomra kiterjedő hatállyal rendelte el, hogy „Ein Züchtigungsrecht steht dem Dienstberechtigten dem Gesinde gegenüber nicht zu” („A szolgálóval szemben a szolgálatra jogosultnak fegyelmezési joga nincs"). Ezért a magyar törvényjavaslat a házi fegyelmi jog kérdésében a 11 évvel korábban megalkotott német törvénnyel szemben is visszaesés volt. ${ }^{12}$

\section{A nők választójoga}

Márkus Dęsố jelentősen megelőzte korát, amikor kijelentette, hogy a nőknek a férfiakkal egyenlő feltételek mellett kívánatos a választójog biztosítása. Erre vonatkozó meggyőződését azzal támasztotta alá, hogy az állampolgárok jogegyenlőségét a Magyarország és Erdély eggyé alakulásáról szóló 1848. évi I. tc. kimondta, amikor a bevezető részében arról szólt, hogy Erdélyben és Magyarországon minden lakos, nemzet, nyelv és valláskülönbség nélkül egyenlő. Az 1868. évi XLIII. tc. 1. \-a értelmében pedig az egyesült Magyarország és Erdély összes honpolgárának az egyenjogúság biztosíttatott polgári és politikai tekintetben is. ${ }^{13} \mathrm{~A}$ fenti jogszabályi rendelkezések ugyan nem szóltak a polgárok nemi értelemben vett egyenlőségéről, azonban Márkus ezen rendelkezésekbool vezette le, hogy a nőket a férfiakkal egyenlően illeti a választójog. ${ }^{14}$

A női választójog kérdésével foglalkozó munkáiban Márkus arra vállalkozott, hogy a férfi szempontjából világítsa meg a témát. A Feministák Egyesületének tagjaként a legnagyobb társadalmi problémák egyikének tartotta a kérdést. Megalkuvás nélküli híve volt a nő választójoga biztosításának, a férfiakkal azonos feltételek mellett. Noha hivatali állása miatt 1910 előtt nem lépett fel nyilvánosan a kérdésben, a Feministák Egyesülete 1909. évi ülésén nyilvánosan beszédet mondott, támogatva a jog megadását. Márkus úgy gondolta, hogy hatályos jogunkban tételes jogi alapja volt annak, hogy a választójogot a nőkre is kiterjesszük, ugyanis a szerző munkássága idején, 1910 és 1912 között a nők választójoga nem került elismerésre Magyarországon. Ellenben az 1848. évi VIII. tc. a közterhek egyenlő viseléséről rendelkezett, az 1868. évi XLIII. tc. egyenjogúságot adott minden honpolgárnak politikai és polgári tekintetben, az 1868. évi XLIV. tc. kimondta, hogy az oszthatatlan egységes nemzetnek minden polgár egyenjogú tagja, az 1912. évi XXX. tc. pedig elrendelte az általános hadkötelezettséget. Ezen törvények mind azt támasztották alá, hogy minden választónak a szavazata egyenlő értékủ. Arra is hivatkozott, hogy a jobbágyság felszabadítása sem csak egyes jobbágyokra terjedt ki, ezért a választójogot sem lehet csupán a férfiakra kiterjeszteni.

Az 1848. évi V. tc. nem szabályozta a női választójogot. Az 1. \-a értelmében mindazok részesültek benne, akik a megyékben és a szabad kerületekben az országgyưlési követek választásában eddig is szavazhattak, vagyis a nemes özvegy nők meghatalmazott által folyhattak bele a választásba. Az 1874. évi XXIII. tc. a nők teljeskorúsításáról szüntette meg Werböcryy Tripartitumának (1517) azon rendelkezését (I.11.), hogy a férfiak 24, a nők 16 éves korukban lettek

\footnotetext{
12 MÁrKuS, Házi fegyelem 98-101.

${ }^{13}$ MÁRKUS, Magyar közjog 198-202.

${ }^{14}$ MÁRKUS, A választójog 3-27.
} 
teljeskorúak, azonban a leányok addig, amíg férjhez nem mentek, mindig másnak a gyámsága és a hatalma alatt álltak. Az 1874. évi XXIII. tc. terjesztette ki a nők magánjogi cselekvőképességét. A törvény 1. \-a szerint a hajadonok 24. életévük betöltésével teljeskorúakká váltak és minden, a teljeskorúsággal járó jog élvezetébe léptek. A kivételt a szabály alól a 2. \ tartalmazta, amely szerint a nő - korára tekintet nélkül - férjhezmenetelével teljeskorúvá vált és e jogot akkor is megtarthatta, ha az 1. \-ban meghatározott életkor betöltése előtt özvegységre jutott, a férjétől a bíróság határozata alapján szétvált, vagy házasságát a bíróság felbontotta. Ennek jelentősége abban állt, hogy a törvény ugyanezt a rendelkezést férfiakra nem tartalmazta. Az 1874. évi választójogi reformtörvény ugyanekkor nem ismerte el a női választójogot. ${ }^{15}$ A 19-20. század fordulóján és az I. világháború éveiben megjelentek azok a politikai pártok, amelyek a nők egyenjogúságát a programjukba tették, így a szociáldemokrata párt a férfiakkal egyenlő választójogért lépett fel. Az 1913. évi XIV. tc. azonban továbbra is kizárta a nőket a választójogból. Meg kell jegyezni, hogy a törvény szerint nem zajlott választás Magyarországon.

A női választójog első jogszabályi rendezése az első néptörvényben történt. ${ }^{16}$ Az 1925 . évi XXVI. tc. szerint - amely alapján három alkalommal folyt országgyűlési választás - a nők esetében nem volt jogkiterjesztés. Az 1938. évi XIX. tc. fenntartotta a női szavazati jogot, de nem adott a nőknek több jogot. A férfiakkal egyenlő választójogot hazánkban is csak az 1945. évi VIII. tv. alapján szerezték meg. ${ }^{17}$

Márkus 1912-ben azt javasolta, hogy a női választójog feltételei a következők legyenek: a magyar állampolgárság (1879. évi L. tc. 8. \, 17. \, 15. \szerint), életkor-érettség, amely a 24. életév betöltése, azaz azonosan a férfiakkal (ezzel szemben a szerző írásakor a hatályos jog szerint az életkor-érettség meghatározására férfiak esetén a 20. életkor került, amelyet a szerző túl kevésnek tartott), a teljes magánjogi és közjogi cselekvőképesség (a Btk. 56. \-a alapján), az írni-olvasni tudás mint legkisebb mûveltségi cenzus és bármely összegű egyenes adó fizetése. Véleménye szerint nagy méltánytalanság lett volna a műveltségi cenzus körében megkövetelni a magyarul írni-olvasni tudást, ugyanis 1867 és 1907 között a törvényhozás és a kormány nem fogta fel a komolyságát a magyar nyelv oktatása szükségességének. Az 1879. évi XVIII. tc. végrehajtását elhanyagolták és a népiskolai közoktatásról szóló 1868. évi XXXVIII. tc. végrehajtása sem valósult meg teljes körűen. ${ }^{18}$ Ugyan az 1907. évi elemi iskolai törvény már megkövetelte a magyar nyelv oktatását, azonban ez idő tájt ténylegesen az egyes nemzetiségek lakta területen a tanítok és a legifjabb nemzedék egy része sem tudott magyarul.

Márkus a választójog megadása körében az állami adó fizetését mint feltételt, azért tartotta szükségesnek, mert így tudott volna a választó a maga gazdasági teljesítményével közvetlenül hozzájárulni az állam szükségleteinek fedezéséhez. Mentesült volna az adófizetési kötelezettség mint feltétel alól az, aki hadkötelezettségét személyesen és valóságosan teljesítette, vagy magasabb értelmi cenzussal bírt, mint a polgári vagy azzal egyenértékủ szakiskola elvégzése, illetve ennél magasabb iskolai végzettség.

\footnotetext{
15 SZEGVÁRI, A nők választójoga 51-70.

${ }^{16}$ SZEGVÁRI, A nők választójoga 95-123.

${ }^{17}$ SZEGVÁRI, Nők választójoga 138-168. Lásd bővebben CSÁsZÁR, Nőmozgalmak 124-125.

18 Lásd bővebben CSÁSZÁR, Eötvös 49-66.
} 
Márkus hangsúlyozta, hogy 1906-ban az ország lakosságának - Horvát-Szlavónország nélkül, amely autonóm választókörű volt - a nagyobbik fele nő volt. A férfiak száma 8,372.819 fö, míg a nőké 8,465.436 fő volt. Tehát a népesség nagyobbik fele csak akként tudott a politikai folyamatokra hatni, hogy a férfiak képviselték. Ez a helyzet nem volt tartható, hiszen döntő befolyása a politikára csak a választóknak lehetett. ${ }^{19}$ A Feministák Egyesületének 1909. évben tartott ülésén mondott beszédét annak szentelte, hogy az akkortájt a Daily Mail hasábjain megjelent „Lord Curzon's fifteen reasons against the grant of Women Suffrage” címú cikknek a női választójog megadása ellen buzdító érveit cáfolja. A cikk írója Lord Curzon of Kedleston volt, egy olyan angol liga vezetője, amely a nő választójoga ellen alakult (Mean's League for Opposing Woman Suffrage). Márkus dicséretesnek tartotta, hogy a szerző nem foglalkozott olyan érvekkel, mint a női test gyengesége vagy a nô szellemi képességének az agyvelő állítólagos kisebb súlyára alapítása, amely nyilvánvalóan haladó nézetre vallott, ugyanakkor vitatkozott a cikkíró véleményével több pontban is.

Márkus egyetértett kortársával abban, hogy a nő legfontosabb hivatása az anyaság, sôt továbbment és azt állította, hogy a férjezett nők a legérdemesebbek arra, hogy az országgyưlési választás jogát gyakorolják. Ugyanakkor cáfolta azt, hogy a politikában történő részvétel kiragadná a nőt az ő legmagasabb hivatásából, az anyaságból. Kiemelte, hogy a nők jelenleg is vállalnak társadalmi szerepet, így pl. jótékonysági mozgalmakban vesznek részt, és választás is csak öt-hat évente van. Fontosnak tartotta, hogy a gyermekét nevelő nő tanult, tájékozott és erkölcsileg szilárd legyen. Lord Curzon of Kedleston szerint a választójog megszerzése az otthon összhangját fogja megtörni, ha a férj és a feleség politikai kérdésekben ellentétes nézeten lesznek. Márkus ezt a leggyengébb ellenérvek egyikének tartotta. Véleménye azt volt, hogy előfordulhat ilyen ellentét, mégis minél intelligensebbek lesznek ezek a házastársak, annál inkább meg fogják érteni, hogy tiszteletben kell tartani a másik meggyőződését.

A nôk előképzettsége hiányát illető félelem kapcsán Márkus kiemelte, hogy a férfiak sem kapnak megfelelő politikai képzést. A felszínes iskolai közjogi tudás pedig nem elégséges arra, hogy az ország ügyeit valaki jól intézze. A férfiak $90 \%$-a részt vett minden előképzettség nélkül a választásban. Még ha a nôi nem túlnyomó többsége nem is óhajtotta a korszakban a politikai választójog megszerzését, ezt olyan abszolút közjognak tartotta, amely nem függhetett egyesek tetszésétől, ahogyan a rabszolgákat sem kérdezték meg a felszabadításuk előtt. Azok, akik bizonyos felekezeti és nemzeti szempontok miatt attól félnek, hogy a nők nagy számának esetleges behatolása a politikába bizonytalanná tehetné az aktuális politika eredményeit, figyelembe kell, hogy vegyék azt a demokratikus tételt, hogy egy politikai pártnak sincs kizárólagos joga többséghez jutni a választásokon. Amennyiben pedig a nők, megszerezvén a politikai jogokat, további, oktatási vagy munkajogokat kívánnak szerezni, felelősségérzetüket is növelni fogja. Egyébként azon pályákon, amelyek már megnyíltak a nők előtt, így a háztartás, mezőgazdaság, kereskedelem, vasúti köztisztviselő, postai alkalmazott, alacsonyabb tisztviselői állások, átlagosan úgy teljesítettek, mint a férfiak. Ugyanakkor Márkus is úgy tartotta még, hogy például a bírói székbe sok nő nem való, mert „a temperamentum megfeleló higgadtságával, megfelelö tárgyilagossággal” nem bírnak, de ez sok férfira is igaz. Elvből kizárni őket erről a pályáról azonban igazságtalan lenne. Azt tartotta a

\footnotetext{
${ }^{19}$ MÁRKUS, A választójog 35-37.
} 
legfontosabbnak, hogy ne csak a lehetőségeik, hanem a kötelességeik is egyenlők legyenek a férfiakéval. $^{20}$

A prostitúció, a házasságon kívül anyává lett nő és az így született gyermek helyzete, a nő családjogi helyzete (amelyet bár a magyar nő tekintetében világszinten a legjobbnak tartott), a női munka anyagi megbecsülése, a női munka védelmének hiánya, az alkoholizmus, a közegészség, a nevelés mind olyan kérdések, amelyeket a férfiuralom nem oldott meg. Kiemelte, hogy több olyan államban, ahol már megkapták a nők a választójogot, pozitív tapasztalatok vannak, így jó hatást gyakorolt a családi életre, a nyilvános erkölcsökre, az együttmúködésre és nem volt hátrányos a nemi erkölcsökre sem (Új Zéland 1908, Washington 1902).

\section{Az özvegyi nyugdíj}

A Jogtudományi Közlöny hasábjain Márkus részletesen foglalkozott a nyugdítörvény módosításával 1909-ben, és ebben a körben az özvegyi nyugdíj kérdésével. ${ }^{21}$ Az özvegyi nyugdij összegét szégyenletesen és kétségbeejtően csekélynek tartotta, amely a legszerényebb megélhetést sem tette lehetővé. Ezért szükségesnek tartotta a nyugdíjtörvény 36. \-ának módosítását. Kiemelte, hogy az özvegy nő sokszor azért nem tudta jövedelmét munkavállalással kiegészíteni, mert a nők nevelésének mai elhibázott módja, amely nem is gondolt annak a lehetőségére, hogy a legjobb anyagi viszonyok közt nevelkedő leány is abba a kényszerítő helyzetbe juthat, hogy férjhezmenetele ellenére is, a maga és családja eltartásáról önmaga gondoskodjék, nem tette lehetôvé. Példaként hozta fel a katonai tisztiözvegyek 1907. évi XVI. tc. által megállapított és az osztrák állami tisztviselők özvegyeinek nyugdíja különbségét. Történt mindez úgy, hogy az utóbbit az 1896. május 14-iki osztrák törvény szabta meg, és rendelkezéseit az 1897. június 2. lf. elhatározás az Ausztriával közös tisztviselőinkre is kiterjesztetté. ${ }^{22}$

\section{A házasságon kívül született gyermek jogállása}

Márkus behatóan foglalkozott a házasságon kívül született gyermek jogállásával a Jogtudományi Közlöny hasábjain 1905-ben és 1907-ben, valamint az Ügyvédek lapjában 1908-ban megjelent írásaiban. Állásfoglalása tükrözte a nőkérdésről alkotott felfogását, amelyről az alábbiakban részletes képet kapunk.

\subsection{A házasságon kívül született gyermek öröklési joga anyja után}

A kir. Curia 1905. szeptember 27-én hozott 6059/1904. számú ítéletével kimondta, hogy „a bírói gyakorlat szerint az atya vagyonában törvényes leszármazók léte esetében is a törvénytelen gyermeket is megilleti az. öröklési jog és ezen a címen a házasságon kivül született gyermeknek is, a törvényes gyermekek mellett, törvényes

\footnotetext{
${ }^{20}$ MÁRKUS, A nő mint köztisztviselő és bíró. 2.

21 MÁRKuS, A nyugdíjtörvény módosítása IV.

22 1897. június 10. 26.641/3. sz. közös külügyminiszteri rendelet, a cs. és kir. külügyminisztérium évkönyvének 427. köv. 1.
} 
osztályrészt juttatote' ${ }^{23}$ A kir. Curia 79. sz. teljes ülési polgári döntvénye kimondta, hogy ,a végrendelet nélkëil elhalt anya bagyatékeára nézve a törvénytelen gyermeknek törvényes leszármazója létezése esetében is van törvényes örökëöödési joga". ${ }^{24}$ Márkus méltatta a Curia fenti határozatát, ugyanis hatályos hazai jogunk - véleménye szerint - a szülők vétkéért a gyermeket életfogytiglan büntetni rendelte. A Curia döntésével megerősített bírói gyakorlat nem volt új keletű, már 30 évvel korábban is született határozat arról, hogy „, a házasságon kivül született gyermek anyja után akkor is örököl, ha annak törvényes leszármazója is maradt’ ${ }^{25}$ Hasonlóképpen döntött a Budapesti kir. Tábla 49.012/1883. sz. ítéletében ${ }^{26}$ és a kir. Curia 1883. évi november 28-án 1926. számú határozatában. ${ }^{27}$

A gyakorlat azonban azóta letért erről az egyedül igazságos, méltányos és emberséges útról, írta Márkus. Az ITSZ I. rész 9. \-ának ama szabályára támaszkodva, hogy a végrendelet nem létében az örökhagyónak minden vagyona a tőle leszármazó törvényes gyermekekre száll, téves gyakorlat alakult ki. ${ }^{28}$ Voltak olyan nézetek, amely szerint az ITSZ törvényt pótló jogszabály és az a házasságon kívül született gyermek öröklési jogát meg nem állapította, azaz a Curia nem helyezheti magát a törvény fölé és nem dönthet mindennek ellenére úgy, hogy a törvényes gyermekekkel együtt, azok mellett is ad az anya után törvényes öröklési jogot a házasságon kívül született gyermeknek. Ezen szigorú értelmezés a házasságon kívül született gyermeknek és anyjának viszonos törvényes öröklési jogát akkor is kizárta volna, ha a házasságon kívül született gyermeknek vagy anyjának törvényes öröklésre jogosult utóda nincs. Vagyis az ITSZ alapján minden olyan esetben, amikor a házasságon kívül született gyermek törvényes örökös vagy végrendelet hátrahagyása nélkül halt meg, az 1715. évi XXVI. tc. és az ITSZ I. rész 18. \-a értelmében a Szent Korona öröklésének kellett helyt fognia. A kir. Curia is osztozott 1824-ben a kir. kincstárnak Katics Anna elleni ügyében ezen állásponton, ${ }^{29}$ ez a gyakorlat azonban szemben állt volna a Curia következetes ítélkezési gyakorlatával - vonta le a következtetést Márkus. ${ }^{30}$

Szerinte a fent ismertetett és kialakult téves gyakorlat nem vezethetô le az ITSZ-ből, ugyanis annak alkotói - a tárgyalások jegyzôkönyveiből kitűnően - a házasságon kívül született gyermekekre nem is gondoltak a szakaszok megszerkesztésekor. A törvényes gyermek, törvényes maradék kifejezés éppen csak ebben az egyetlen 9. \-ban fordult elő. Ellenben nem szerepelt ez a megkülönböztetés a szabályok más részeiben, ahol leszármazókról volt szó. Márpedig, ha az Országbírói Értekezlet tagjai tudatosan különbséget akartak volna tenni a házasságban és azon kívül született gyermekek közt, ezt a megkülönböztetést nem szorították volna a 9. \-ra, hanem kifejezetten megtették volna azt a törvényes öröklést (vagy az idézett törvény szavaival élve: a végrendelet nélküli öröklést) szabályozó összes szakaszokban. Ezért arra a következtetésre kell jutnunk, véli Márkus, hogy ott, ahol az ITSZ általánosságban csak leszármazókról beszélt, az összes lemenőket kell értenünk, tekintet nélkül származásuk törvényességére.

\footnotetext{
${ }^{23}$ MÁRKUS, A házasságon kívül született gyermek öröklési joga 357-358.

${ }^{24}$ MÁRKUS, A házasságon kívül született gyermek és joggyakorlatunk. I. 1-2.

25 2497/1874. sz. Dt. r. f. XII. 122. 1.

${ }^{26}$ Felsőbíróságaink elvi határozatai II. 2359.

${ }^{27}$ Felsőbíróságaink elvi határozatai II. 2358.

${ }^{28}$ MÁRKUS, A házasságon kívül született gyermek öröklési joga 357-358.

${ }^{29}$ FogARASSY, Magyar Közpolg. 168. 1., 372. 』

${ }^{30}$ MÁRKUS, A házasságon kívül született gyermek és joggyakorlatunk. I. 1-2.
} 
Osztotta Márkus Kern Tivadar véleményét (öröklési jog 14. \$.), aki szerint az Országbírói Értekezlet a házasságon kívül született gyermek öröklési jogának kérdésében hallgatólagosan fönntartotta az 1848 előtt fönnállott jogunk álláspontját, amely azt csaknem teljesen kizárta az örökségből. Ily módon a kérdés megoldása a joggyakorlatra maradt, amely azt Márkus szerint egyrészt humanizmusból, másrészt az osztrák polgári törvénykönyv (OPTK) 754. \-ának hatása alatt („, az anyára nézve a házasságon kivüili gyermekeek, a szabadon elörökithetö vagyonbani örökösödést illetöleg, a törvényes gyermekekekel egyenlö jogokkal birnak") kedvezően oldotta meg, később azonban gyakorlatunk letért erről a helyes ösvényről és az ITSZ idézett szabályára támaszkodva nem ismerte el a házasságon kívül született gyermeknek a törvényes gyermekkel konkuráló öröklési jogát az anya hagyatékában, ${ }^{31}$ hanem csak azt, hogy végrendelet és törvényes leszármazók hiányában örökölt - esetleg a felmenőkkel együtt - az oldalági örökösökkel szemben, akik az ITSZ 12. \-a alapján követelték az örökséget. Az anyai rokonokkal szemben tehát nem ismerte el a házasságon kívül született gyermek törvényes örökösi jogát.

Márkus azt remélte, hogy a kir. Curia 1905. szeptember 27-én hozott ítélete nyomán legfőbb bíróságunk nem fog megmaradni ezen a rideg állásponton és visszatér az osztrák joggyakorlat példájához annál is inkább, mivel a magyar polgári törvénykönyv 1900. évi tervezete 343. 』-ában kimondta, hogy a törvénytelen gyermek anyjának és anyja rokonainak épp oly rokona, mintha törvényes származású volna. Ebből pedig természetszerúen következett, hogy a törvénytelen gyermek anyjának és anyja rokonainak örököse. Márkus hangsúlyozta, hogy azonos állásponton volt a német BGB is (1705. 』 és 1924. \)..$^{32}$

Márkus szerint sajnálatos, hogy a Curia ítéleteinek többsége a 79. számú döntvénnyel ellenkező értelemben határozott. ${ }^{33}$ Ezeknek az ítéleteknek az indokolása szerint a bírói gyakorlat a törvénytelen gyermekek öröklésére nézve csak azt állapította meg jogszokásul, hogy a házasságon kívül született törvénytelen gyermek örökösödik végrendelet nélkül elhunyt anyja vagyonában akkor, midőn az anya nem hagyott hátra házasságból származott törvényes gyermeket. Ez a gyakorlat nem is ütközött az ITSZ 10. és 12. \$S-ba, amelyek leszármazók hiányában szabályozták a felmenők és az oldalágiak öröklését anélkül, hogy a leszármazók törvényességét hangsúlyozták volna, és a törvénytelen gyermeket a felmenőkkel és az oldalágiakkal szemben kizárnák az anyai örökségből. De nem így van ez az ITSZ leszármazók öröklését szabályozó 9. 『-ában, amely világosan rendelte, hogy végrendelet nem létében az örökhagyónak minden vagyona a tőle leszármazó törvényes gyermekekre száll. Ezen rendeletével a „törvény” - hangsúlyozván a hagyaték összességét és a leszármazó törvényességét - kizárta a törvénytelen gyermeket a törvényes gyermek javára az anyai örökségből is és a fennálló tételes törvénnyel ellenkező gyakorlat és jogszokás pedig nem keletkezik. ${ }^{34}$ Márkus a 79. számú polgári döntvényben foglaltakkal értett

\footnotetext{
${ }^{31}$ Curia 1884. január 9. 3941/83. sz., 1885. október 6. 1181. sz., 1888. május 1. 10,369. sz., lásd Felsőbíróságaink elvi határozatai II. 226-227. 1., 1892. évi április 21. 6000/91. sz., u. o. 229. 1., 1898. szeptember 7. 1473. sz., lásd Felsőbíróságaink elvi határozatai X. 174.1., 1902 márczius 13. 3067/901. sz., lásd Felsőbíróságaink elvi határozatai XIII. 298. 1.

32 MÁRKUS, A házasságon kívül született gyermek öröklési joga 357-358.

${ }^{33}$ MÁRKuS, A házasságon kívül született gyermek és joggyakorlatunk. II. 12-14.

34 Legfelsőbb Bíróság, 1884. január 9. 3941/1883. sz., azonos határozatok: 8964/93, 1474/98, 5937/98, 1980/900, 4650/900, 1208/901, 7472/901, 6267/903, 3698/903.
} 
egyet. Álláspontja szerint az ITSZ ereje nem volt azonos a törvény erejével, és nem zárta ki a Curia jogfejlesztő tevékenységét, sőt szükségessé tette azt. ${ }^{35}$

\subsection{A házasságon kívül született gyermek tartáshoz való joga}

Márkus rá kívánt mutatni arra, hogy bíróságaink egy része nem járt el méltányosan a házasságon kívül született gyermek tartási jogát tekintve és nem vette figyelembe a kérdés társadalmi jelentőségét. ${ }^{36}$ Vizsgálata idején a kir. Curia tehermentesítése céljából a házasságon kívül született gyermek tartási jogára vonatkozó perek a főbíróság hatásköréből a tizenegy ítélőtábla hatáskörébe kerültek. Ezek közül a marosvásárhelyi és - a korábban Zaránd megyéhez és Kővár vidékéhez tartozó néhány község kivételével - a kolozsvári táblabíróságok egészen, a temesvári táblabíróság jó részben, a debreceni és budapesti tábla pedig kis részben az OPTK rendelkezéseit volt köteles alkalmazni a tartási perekben. Márkus szerint ez azt a veszélyt hordozta magában, hogy ezekben az ügyekben a kir. Curia felülvizsgálati bíráskodása által nagy nehezen létesített jogegység csakhamar felbomlik és újból a legkülönbözőbb jogi felfogással találkozhatunk. ${ }^{37}$

Hangsúlyozta, hogy alsóbb bíróságaink némelyike továbbra is nevetségesen alacsonyan állapította meg a tartásdíj összegét, átlagosan 10-12 Koronában, de találkozott 5-6 Korona körüli összegekkel is. Erre abból a téves felfogásból került sor, hogy a házasságon kívül született gyermek eltartásának kötelessége elsősorban az anyára hárult. Ez a felfogás azonban elemi jogtételbe ütközött, ugyanis az OPTK 167. \-a világos volt e tekintetben és azok a törvénykönyvek, amelyek a gyermeknek vagy anyjának kereseti jogot adtak a házasságon kívüli atyával szemben, ugyancsak az apát mondták elsősorban tartásra kötelesnek (BGB 1709. §). A magyar polgári törvénykönyv 1900. évi tervezetének 348. \-a is ezeket javasolta törvénybe iktatni, jelesül úgy szólt, hogy „A törvénytelen gyermeket természetes atyja eltartani köteles. Kötelezettsége megelózi az anyáét és az anyai ágbeli rokonét'. Márkus úgy vélte, hogy a tartásdíj csekély összege szemben áll az OPTK 166. \-ában rögzített szabállyal, amely szerint a gyermek a szülője vagyonához mért „ápolást, nevelést és ellátást'követelhetett. A magyar polgári törvénykönyv 1900. évi tervezete - ami a századforduló éveiben már világosan befolyásolta a bírói joggyakorlat alakulását ${ }^{38}$ - álláspontja szerint a gyermeket eltartás címén mindaz megillette, amely az illő megélhetéséhez kellett, nem pedig csak a szükséges tartás, valamint az is, amibe neveltetésének és kiképeztetésének költsége került (349. §). Az uralkodó jogi fölfogás szerint a házasságon kívül született gyermek tartását a természetes atya vagyoni és kereseti viszonyai figyelembevételével, az anya társadalmi állásához mérten kellett megszabni (350. 』), ahogy ezt a BGB 1708. 』-a is rendelte. Ezt Márkus célzatosan egyoldalúnak tartotta, ugyanis az anya az esetek túlnyomó többségében a szegényebb társadalmi osztályokból került ki. Véleménye szerint a törvényhozás a férfit védte, ezért a cseléd gyermeke, legyen az apja bármilyen tekintélyes állású ember, nem is álmodhatott arról, hogy valaha jobb sorsra juthat.

Hangsúlyozta azt, hogy a magyar bírót semmiféle törvényes szabály nem gátolta abban, hogy emberies fölfogást vigyen a joggyakorlatunkba. Sőt, az a körülmény, hogy az ország oly nagy

\footnotetext{
35 MÁRKUS, A házasságon kívül született gyermek és joggyakorlatunk. II. 12-14.

${ }^{36}$ MÁRKUS, A házasságon kívül született gyermek és joggyakorlatunk. IV. 315-317.

${ }^{37}$ MÁRKUS, A házasságon kívül született gyermek és joggyakorlatunk. III. 35-36.

${ }^{38}$ HerGER, A modern magyar házassági vagyonjog 431.
} 
területén hatályos OPTK 166. \-ában azt rendelte, hogy a házasságon kívül született gyermek a szüleitől követelhet „vagyonukhoz mért’ ápolást, nevelést és ellátást, lehetővé is tette ezt az ítélkező bírák számára. Ilyen előremutató példa volt a kir. Curiának 1906. I. G. 293. számú ítélete, amely alapján az atyát, aki vezérkari őrnagy volt, a házasságon kívül született gyermeke 22 éves koráig a középiskolai oktatása költségeinek viselésére is kötelezte annak ellenére, hogy a gyermek anyja egy haszonbérlő leánya volt.

A tartás időtartamát is rendkívül méltánytalanul szabták meg a bíróságaink Márkus véleménye szerint, a Curia pedig - a vizsgálat idején - már 13 év óta nem hozott érdemi határozatot ebben a kérdésben. A fellebbezési bíróságaink szerint a leánygyermek 12, a fiúgyermek legfeljebb 14 éves korában annyira keresőképes volt, hogy apjának tartásdíjára már nem szorult. Úgy gondolta, hogy nem hoztak volna hasonló döntést a bíróságok a házasságban született gyermek tekintetében, vagyis a 12 vagy 14 éves házasságban született gyermek apját nem mentették volna fel a tartás kötelezettsége alól azzal az indokkal, hogy az ilyen korú gyermek már önálló keresetre képes. ${ }^{39}$ Kiemelte, hogy az osztrák bírósági gyakorlat már évtizedek óta azon az állásponton volt, hogy a tartás megszabásánál inkább a gyermek, mint az apa érdeke a figyelembe veendő szempont. ${ }^{40}$ Azt is kimondta az osztrák bíróság, hogy a gyermek serdültségének bekövetkezése nem szünteti meg a tartási kötelességet, ${ }^{41}$ hanem a nevelés befejezése után beáll az ellátás követelésének joga avégből, hogy a gyermek mentes maradjon az anyagi fenntartás gondjaitól, valamint a mesterségre való taníttatás az osztrák joggyakorlatban nem merítette ki az ellátás kötelességét. ${ }^{42}$

A kialakult hazai bírói gyakorlattal az is ellentétben állt Márkus véleménye szerint, hogy a 12. vagy 14. életévet még a mi törvényeink sem tekintették az önálló keresőképesség korbeli határának. A gyámságról szóló 1877. évi XX. tc. 26. \-a szerint az atyai hatalom alatt álló kiskorúak, ha 16. életévüket meghaladták és az életpálya választásánál atyjokkal egyet nem értettek, előterjesztést tehettek a gyámhatóságnál. Az 1900. évi magyar javaslat 350. \-a szerint (amely egyezett a BGB 1708. \-ával), a gyermek 16 éves koráig nyújtotta az apa a tartást. Amennyiben azonban a gyermek még e kor elértével is rászorult a tartásra, az atya kötelezettsége a gyermek teljeskorúvá válásáig tartott. Márkus úgy vélte, hogy a hazai joggyakorlat volt a legkevésbé méltányos ebben a kérdésben. ${ }^{43}$

Azt is méltatlannak tartotta Márkus, hogy a kialakult gyakorlat a múltra nézve csak akkor állapította meg a tartásdijat, ha az anyát tőle nem függő körülmények gátolták a keresetnek kellő időben történt megindításában annak érdekében, hogy az atyát az évek múltán az egy összegben követelt díjak vagyonilag tönkre ne tegyék. Továbbá azzal sem értett egyet, hogy a szülés költségét a joggyakorlat csak csábítás vagy erőszak esetén ítélte meg az anya részére. Az osztrák gyakorlat nem ismerte ezt a megszorítást. Az 1900. évi magyar javaslat - a BGB 1715. \-át követve - 356. 』ában úgy rendelkezett, hogy ,aそ atya köteles az, anyának a szülés költségét és a szülést követo” hat hétre életfenntartásának költségét, esetleg a terhesség és sqülés követkętében felmerült kiadásait megtéríteni. Az anya a rendesnél nem nagyobb, ilynemü költségeket követelheti, tekintet nélkül arra, hogy volt-e és mennyi volt a tényleges

\footnotetext{
${ }^{39}$ MÁRKUS, A házasságon kívül született gyermek és joggyakorlatunk. IV. 315-317.

40 Osztrák legfőbb törvényszék 1860. december 18. 10.927. sz. Unger Glaser gyújt. 1248.

${ }^{41}$ U. o. 1884. szeptember 11. 10.264. sz., 1891. január 25. 13.799. sz., Unger Glaser gyüjt. 10.155. és 13.587. sz.

42 U. o. 1871. december 21. Unger Glaser gyüjt. 11.137.

${ }^{43}$ U. o. 1884. július 3. 7461. sz. gyűjt. 10.100. sz.
} 
kiadása”. A 358. \. szerint pedig az anya ezeket a követeléseket három éven belül akkor is érvényesíthette, ha a gyermek halva született, vagy a gyermek születése előtt az atya meghalt. Márkus álláspontja szerint kívánatos lett volna, hogy joggyakorlatunk ilyen irányba induljon el a szülési költség megszabásánál is. ${ }^{44}$

\subsection{A házasságtörésben nemzett gyermekek törvényesítése ${ }^{45}$}

Az OPTK 67. \-a érvénytelennek mondta ki azok házasságát, akik egymással házasságtörést követtek el, azonban ugyanez a kódex nem zárta ki a házasságtörés útján nemzett gyermekek törvényesítését. Márkus szerint semmiféle elfogadható érv nem hozható fel az elismerés tilalma mellett, ugyanis megtörténhet, hogy az utólagos házasság útján való törvényesítés az érdekeltek hibája nélkül (pl. az anya halála következtében) lehetetlen. Egyébként is, ha az érdekeltek jóvátehetik a házasságtöréssel elkövetett vétküket olyképpen, hogy egymással házasságot köthetnek, akkor semmiféle erkölcsi szempont sem szólhat amellett, hogy csakis az ártatlan gyermek bűnhődjék élte fogytáig.

Helytelennek tartotta az 1900. évi magyar javaslat 2002. \-nak rendelkezését, amely szerint „az utólagos házasság által való törvényesités joghatálya kiterjed a gyermek ivadékaira akkor is, ha a gyermek a házasság megkötése elött meghalt”. Az indokolás szerint „hasonló szabályozást tartalmaznak a külföldi törvényhozások kö̃ül a német (1722.), olasz (196.), a Code civil (332.).“ Azonban a tervezet helytelenül hivatkozott a fenti példákra, különösen mert a tervezet 212. \-a szerint „halála után a gyermek nem törvényesithetó akekor sem, ha ivadékai vannak", tehát a magyar javaslat homlokegyenest ellentétesen rendelkezett az olasz, a francia és különösen a svájci joggal, ahol „a korábban elhalt gyermekek törvényesitése ivadékaik érdekében is helyt foghatote' (Code civil 332. cikk).

Márkus rámutatott arra is, hogy amikor azt a különbséget akarták a korszak jogászai kidomborítani, amely a házasságon kívül született gyermek apasága tekintetében egyfelől a francia, másfelől a többi kontinentális jogrendszer között fennállt, akkor rendszerint a Code civilnek 340. cikkéből idézték annak híressé vált első mondatát, amely szerint „az apaság kutatása tilos”. A különbség nem is annyira éles azonban. Sem nálunk, sem Ausztriában, sem a Német Birodalomban, sem Svájcban nem volt megengedve az apaság kutatása oly célból, hogy a bíróság valakit a házasságon kívül született gyermek apjának nyilvánítson. Nálunk sem volt kereset egyébre, mint arra, hogy a bíróság azt a férfit, akiről megállapította, hogy a gyermek apja, annak 12 vagy legföljebb 14 éves koráig tartásra szorítsa. Tehát az ítélet csak azt mondhatta ki, hogy az alperes férfiú a felperes nő házasságon kívül született gyermekének az apja és a bíróság az alperest nevetségesen rövid időtartamra, még nevetségesebben megszabott pénzbeli tartás szolgáltatására kötelezte. Azt nem mondta ki, hogy az alperes, mint a gyermeknek bebizonyult apja, köteles azzal szemben az apasággal járó összes kötelességeket teljesíteni. ${ }^{46}$

\footnotetext{
${ }^{44}$ MÁRKUS, A házasságon kívül született gyermek és joggyakorlatunk. V. 337-339.

${ }^{45}$ MÁRKUS, A házasságon kívül született gyermek a legújabb jogfejlődésben III. 2.

${ }^{46}$ MÁRKUS, A házasságon kívül született gyermek a legújabb jogfejlődésben IV. 2-3.
} 


\section{Következtetések}

Márkus Dęső ismertetett munkái alapján egyértelmú, hogy a női (következetes) jogegyenlősítés támogatója volt úgy, hogy annak egyes területeit tekintve saját korának felfogását jócskán meghaladta. A jogegyenlőség feltétlen híveként pártolta a választójog nőkre történő kiterjesztését a férfiakkal azonos feltételek mellett. Épp ilyen hevesen ellenezte a gazda fegyelmi joga gyakorlását a cseléd felett. A házasságon kívül született gyermek jogállásának vizsgálata kapcsán méltatlannak tartotta, hogy a korabeli jogi normák nem becsülték megfelelően az emberi életet, hiszen a házasságon kívül született gyermek után fizetendő tartásdíjat úgy fogták fel, mint a férfi részéről az élvezetekért fizetett összeget. Az így született gyermek egész élete tele volt azonban testi, lelki, erkölcsi nyomorúsággal. A bíró ugyan nem tehette jóvá a társadalom és a törvényhozás mulasztásait ezen a téren, mégis módjában állt azoknak hatását enyhíteni, amely Márkus véleménye szerint egyben a kötelessége is volt.

Márkus összehasonlító jogi módszerrel dolgozott. Tudományos igényességgel vizsgálta a fenti témák esetében a külföldi törvényhozások eredményeit. A célja az volt, hogy a készülő magyar polgári kódex végleges szövegének kialakítását elősegítse úgy, hogy a társadalom elesettjei kedvezőbb jogállást élvezhessenek, miközben a korabeli társadalom többségének elvi álláspontját is figyelembe veszi a jogalkotó. Azzal azonban tisztában volt, hogy az olyan gyökeres reformnak, amelyet ő az elesettek érdekében szükségesnek tartott, még nem érkezett el az ideje. ${ }^{47}$

\section{Felhasznált irodalom}

CSÁSZÁr Kinga: A cselédség jogi helyzete a dualizmus-kori Magyarországon. Cselédügyek Somogyban és Baranyában. Jura 2013/2. 171-180.

CsÁszÁr Kinga: Eötvös József és az intézményes nőnevelés Somogyban. In: Varga Norbert (szerk.): VI. Szegedi Jogtörténeti Napok báró Eötvös József születésének 200. évfordulója alkalmából. Szegedi Tudományegyetem Állam- és Jogtudományi Kar Magyar Jogtörténeti Tanszék. Szeged 2014, 49-66.

CSÁSZÁr Kinga: Nőmozgalmak a dualizmus-kori Magyarországon (1867 - 1918). Jura 2013/1. 117-128.

FOGARASSY János: Magyar Közpolg. törvénytudomány elemei, Kövy Sándor után. 6. kiadás. Budapest 1847

MÁRKUS Dezső: A házasságon kívül született gyermek a legújabb jogfejlődésben I. Ügyvédek lapja 1908/19. 5.

MÁRKUS Dezső: A házasságon kívül született gyermek a legújabb jogfejlődésben III. Ügyvédek lapja 1908/21. 2-3.

MÁRKus Dezső: A házasságon kívül született gyermek a legújabb jogfejlődésben IV. Ügyvédek lapja 1908/23. 2-3.

\footnotetext{
${ }^{47}$ MÁRKUS, A házasságon kívül született gyermek a legújabb jogfejlődésben I. 5.
} 
MÁRKuS Dezső: A házasságon kívül született gyermek és joggyakorlatunk. I. Jogtudományi Közlöny 1907/1. 1-2.

MÁRKuS Dezső: A házasságon kívül született gyermek és joggyakorlatunk. II. Jogtudományi Közlöny 1907/2. 12-14.

MÁRKus Dezső: A házasságon kívül született gyermek és joggyakorlatunk. III. Jogtudományi Közlöny 1907/5. 35-36.

MÁRKus Dezső: A házasságon kívül született gyermek és joggyakorlatunk. IV. Jogtudományi Közlöny 1907/39. 315-317.

MÁRKus Dezső: A házasságon kívül született gyermek és joggyakorlatunk. V. Jogtudományi Közlöny 1907/41. 337-339.

MÁRKuS Dezső: A házasságon kívül született gyermek öröklési joga anyja után. Jogtudományi Közlöny 1905/44. 357-358.

MÁRKus Dezső: A nô mint köztisztviselő és bíró. Ügyvédek lapja 1910/30. 2.

MÁRKuS Dezső: A nyugdíjtörvény módosítása IV. Jogtudományi közlöny 1909/32. 273-275.

MÁRKus Dezső (szerk.): Felsőbíróságaink elvi határozatai. Budapest 1891 - 1912

MÁRKus Dezső: Házi fegyelem gyakorlása. A nő és a társadalom. A Feministák Egyesülete és a Nőtisztviselők Országos Egyesülete Hivatalos közlönye. 1907/6. 98-101.

MÁRKUS Dezső: Magyar közjog. A hatályban lévő tételes jogforrások alapján. Budapest 1910

MÁRKus Dezső: A nő választójoga. Dr. Márkus Dezső beszéde a Magyarországi Nőegyesületek Szövetsége Választójogi Szakosztályának ülésén. 1910. április 28. napján. A Férfiliga a nő választójoga érdekében. Budapest 1910

MÁRKus Dezső: A választójog. A nő választójoga. Két tanulmány. Budapest 1912

NAGYNÉ SZEGVÁRI Katalin: A női választójog külföldön és hazánkban. Budapest 2001

NAGYNÉ SZEGVÁRI Katalin: Út a nők egyenjogúságához. Budapest 1981

RÁCZ Gyula: A cselédtörvény javaslat bírálata. Budapest 1909

SÁPI Vilmos: A mezőgazdasági cselédség magánjogi helyzete a dualizmus korában. In: CSIZMADIA Andor (szerk.): Jogtörténeti tanulmányok II. A dualizmus korának állam- és jogtörténeti kérdései. Budapest 1968, 299-310.

SzILI Ferenc: Cselédsors az uradalmas Somogyban a két világháború között. Kaposvár 1976 T. MÉREY Klára: Adatok a déldunántúli uradalmak gazdasági cselédségének életviszonyaihoz a századforduló idején. Pécs 1957 